\title{
IDENTIFYING THE RULES FOR IDENTIFYING CUSTOMARY INTERNATIONAL LAW: RESPONSE FROM MICHAEL WOOD AND OMRI SENDER
}

\author{
Michael Wood* and Omri Sendert
}

We are grateful to AJIL Unbound for organizing this symposium on the work of the International Law Commission on identification of customary international law. We are particularly grateful to all who have contributed to the symposium for their interest and insights.

We shall not here reply comprehensively to everything that has been said. Many points will be addressed in the Special Rapporteur's third report, to be submitted to the UN Secretariat toward the end of March 2015 in preparation for the Commission's session beginning in May 2015. We would only say that many of the points made in the symposium thus far seem eminently sensible, and will hopefully be seen as such by the Commission. It has to be noted, however, that the work of the Commission is collegiate, and the eventual output does not belong to the Special Rapporteur (who is just a facilitator) but to the Commission as a whole-and eventually to the General Assembly and the international community.

We would question the description of the Commission as "conservative," a somewhat loaded term used by Edward Swaine ${ }^{1}$ and Daniel Bodansky. ${ }^{2}$ The views and backgrounds of ILC members are varied and cannot be summed up in a single word. It may be noted that, despite some clearly "reformist" approaches voiced within the Commission with respect to other topics in its current program of work, the so-called conventional view of customary international law (as comprising both a general practice and acceptance of such practice as law) is fully supported within the Commission. But lest it be thought we protest too much, it should be recalled that the Commission's object, under its Statute, is the promotion of the progressive development of international law and its codification. In order to do that it must adopt a real-world approach and provide drafts that will hopefully prove useful and acceptable to the international community.

The current postings in the symposium fall into three categories: those that appear to question the basic approach adopted thus far by the Commission (Bodansky); those that raise questions and make suggestions in a particular field (David DeBartolo, ${ }^{3}$ on the role of international organizations in the customary process, and Jeremy Sharpe, ${ }^{4}$ on investment arbitration); and those that raise points arising from particular wording in the current Draft Conclusions (Bernard Oxman ${ }^{5}$ and Swaine). Sean Murphy, ${ }^{6}$ with inside knowledge of the

* Member of the International Law Commission, Special Rapporteur for identification of customary international law.

† Counsel for The World Bank.

Originally published online 8 Jan. 2015.

${ }^{1}$ Edward T. Swaine, Identifying Customary International Law: First Thoughts on the ILC's First Steps, 108 AJIL UnBOUND 184 (2014).

2 Daniel Bodansky, Does Custom Have a Source?, 108 AJIL Unbound 179 (2014).

${ }^{3}$ David M. DeBartolo, Identifying International Organizations' Contributions to Custom, 108 AJIL UnBound 174 (2014).

${ }^{4}$ Jeremy K. Sharpe, The Potential Impact on Investment Arbitration of the ILC's Work on Customary International Law, 108 AJIL UNBOUND 188 (2014).

${ }^{5}$ Bernard H. Oxman, Some Observations on the Draft Conclusions on Identification of Customary Law Provisionally Adopted by the ILC's Drafting Committee at the Sixty-sixth Session (2014), 108 AJIL UNBOUND 193 (2014).

${ }^{6}$ Sean D. Murphy, Identifying the Rules for Identifying Customary International Law, 108 AJIL UnBound 169 (2014).

ASIL, Michael Wood, and Omri Sender (C) 2015 
Commission, draws attention to a number of "potential flash points" that would certainly benefit from additional thought and comment.

In taking up this topic, the Commission was conscious of the need to secure a common understanding of the process of identifying customary international law among all those who are called upon to apply it (not least given the considerable theoretical differences to be found in the writings). Sharpe's post on the potential impact of the Commission's work on investment arbitration well reflects the aim of the topic and gives powerful support for its utility. Bodansky, on the other hand, clearly disagrees with the Commission's approach; he seems to take the Commission to task for not adopting his own approach to the identification of customary international law, an approach that would apparently have practitioners move away from the Statute of the International Court of Justice. He seeks to place international law into just two categories, distinguishing between "treaty and non-treaty law", thus effectively merging customary international law and general principles of law. But is Bodansky's approach so different from what he terms the "official story" or, borrowing from Reisman, the "myth system"? He says that "customary international law actually involves three interrelated but distinct phenomena," which he describes as "the practice of international tribunals deciding cases," "the discursive practice of states and expert bodies," and "behavior rather than speech." Yet all these clearly have a role in the "conventional view": practice encompasses both words and deeds, and may very well be influenced by (and influence) decisions of international courts and tribunals. Bodansky then wonders "whether political decision-makers within states accept a secondary rule of non-treaty lawmaking, the products of which they recognize as law"; the response by States to the Commission's output on the topic may answer that question.

Swaine suggests that the Commission's expansive and inclusive approach to the identification of rules of customary international law might undermine the attempt to "provide better advice to less expert actors." But the Commission's approach reflects and seeks to preserve the inherently flexible nature of this source of international law, which such actors necessarily need to appreciate. The overarching principle provided in Draft Conclusion 3, according to which regard must be had to the overall context and particular circumstances associated with any evidence of customary international law, should serve to alleviate some of the concerns raised by Swaine and Oxman in this context.

One outstanding issue for the Commission is the role of international (intergovernmental) organizations in the customary process. Here DeBartolo and others (including Murphy) have presented us with much to think about. The third report will attempt to address such issues, and further input would be welcome now or at a later stage in the Commission's work. We would recall that, as suggested in the second report, in approaching this matter it ought to be recognized that "[t]he subjects of law in any legal system are not necessarily identical in their nature or in the extent of their rights" (as the International Court said in the Reparation Opinion); and that international organizations vary greatly one from another, a fact that needs to be borne in mind when assessing the significance of their practice. Such considerations indeed bring us back to the centrality of States in the customary process. In any event, when referring to the practice of international organizations, we are not talking about what Oxman refers to as "practices of individuals entrusted with functions under a treaty"; the relevant practice would be that of the organization or one of its organs (just as acts of individuals may be seen as those of a State).

The draft conclusions on identification of customary international law (together with the eventual commentaries) are a work in progress; we believe that the perceptive comments made in this symposium will contribute significantly to the final output. One of the advantages of the Commission taking up a topic is that it stimulates debate-within governments, universities, and other learned societies and organizationswhich itself contributes to greater understanding and knowledge of the law. This has already been the case 
with the topic of identification of customary international law, at a time when greater clarity is surely desired. We look forward to further debate on this topic in the future. 